\title{
ENSAIO
}

\section{MIGRANTES, NÃO LUGARES E LUGARES DE MEMÓRIA}

ZILMA BORGES, professora da FGV-EAESP, zilma.borges@fgv.br

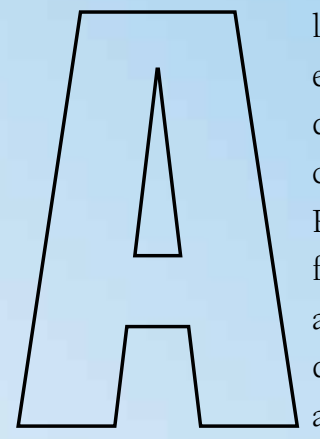

lgum tempo atrás, visitei a exposição Deslocamentos, da artista multimídia gaúcha Marie Ange Bordas. Por meio de instalações, fotografias e vídeos, a artista mostra experiências de refugiados vivendo em albergues na França, na África do Sul e no Quênia, e documenta histórias de vida caracterizadas pelo deslocamento forçado e pela quase impossibilidade de voltar.

As sociedades sempre tiveram suas formas de separar os estranhos. Hospícios e prisões são duas delas, ao afastarem do espaço compartilhado as pessoas que transgridem a norma. Mas não são as únicas: nas grandes cidades, em especial, são diversos os mecanismos explícitos ou tácitos de controle social, a separarem os "estranhos" dos "pertencentes".

Atualmente, a população de migrantes do mundo é de aproximadamente 215 milhões de pessoas, o que equivale a um em cada 33 habitantes do globo - muitos deles, sujeitos a esses mecanismos de separação. O fluxo tem se ampliado cada vez mais por razões que vão do campo político ao econômico-laboral, e o fenômeno sugere o declínio das identidades vinculadas a uma ancoragem estável dos indivíduos ao mundo social.
O antropólogo francês Marc Auge trata de um conceito muito interessante para entender esse fenômeno. Trata-se do não lugar, nome dado ao tipo de espaço que a sociedade atual tende a criar, caracterizado pelo deslocamento e pela solidão. Não lugares definem-se em contraposição aos lugares que têm sentido para aqueles que os habitam. Eles estão além dos espaços em que indivíduos e grupos se definem como iguais, em relações sociais, e carecem de três características comuns ao conceito antropológico de lugar: não são identitários, não são relacionais e não são históricos. Caracterizam-se, ao contrário, pela individualidade solitária, pela passagem, pelo provisório e efêmero. São exemplos emblemáticos os aeroportos, as grandes cadeias de hotéis, alguns espaços públicos e determinados ambientes organizacionais locais que, muitas vezes, só põem o indivíduo em contato com uma outra imagem de si mesmo.

Quando não há, nos espaços de chegada dos migrantes, lugares possíveis para ancoramento, as referências e os locais de origem continuam a representar a fonte estruturante de identidades, mediante um resgate constante dos lugares do passado. Temos aí a perspectiva de vidas com significados que podem acabar permanecendo no tempo perdido das lembranças, nos "lugares de memória" distantes de novos sentidos.

Mas que lugares são esses? Em seus livros $O$ tempo vivo da memória e Memória de velhos, a psi- 

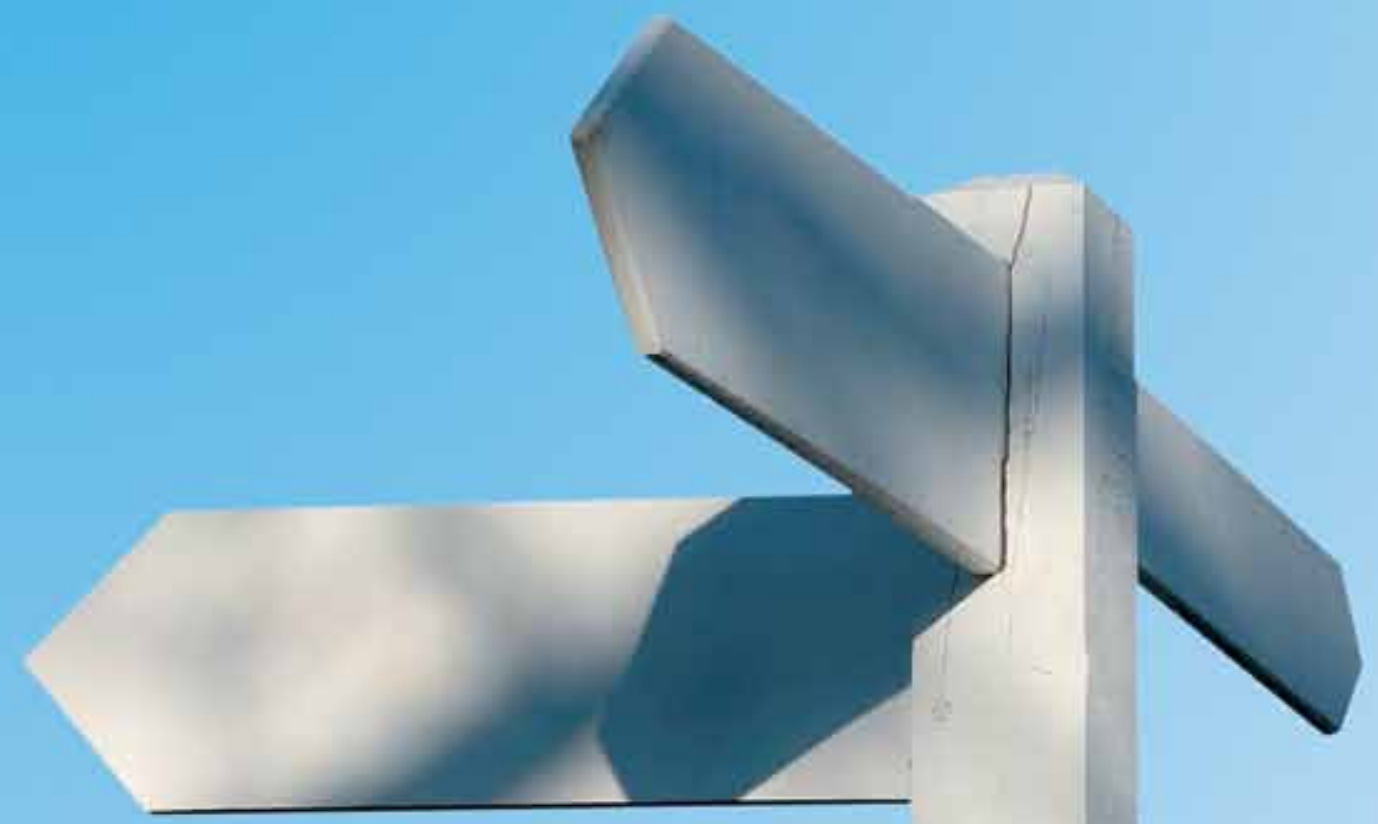

cóloga Ecléa Bosi afirma que, na maior parte das vezes, lembrar não é reviver, mas refazer, com imagens e ideias de hoje, as experiências do passado. Deve-se duvidar da sobrevivência do passado "tal como foi", uma vez que a lembrança é uma imagem construída pelos materiais que estão, agora, à nossa disposição. A lembrança de fatos não é a mesma imagem que experimentamos no passado, porque nós não somos mais os mesmos: nossa percepção alterou-se e, com ela, nossas ideias, nossos juízos de realidade e de valor.

Assim, podemos dizer que, nos lugares de memória, aprendemos essencialmente nossos contrastes - a imagem do que não somos mais. E essa é uma noção importante: os lugares de memória podem ser os guardiões de um passado que nos prende e impede de seguir adiante, mas podem também representar o papel inverso e facilitar o contato com o novo, quando percebermos que não nos perderemos de nós mesmos em meio às novas experiências. Podem ser uma armadilha ou uma tábua de salvação.

Qual dos dois papéis exercerão, dependerá do grau de autonomia e liberdade dos indivíduos em relação às proposições e valores do conjunto social. Dependerá, também, da compreensão das possibilidades de vivências que permitam trocas significativas entre a dimensão privada e a pública da vida, o alcance do senso de comunidade local e de direitos universais, da diferença e da desigualdade.

\section{$\boldsymbol{A}$ RECORDAR NÃO É VIVER. LEMBRANÇAS PODEM SER UMA ARMADILHA QUANDO NOS IMPEDEM DE SEGUIR ADIANTE}

